\begin{tabular}{|c|c|}
\hline Journal of Technology & Volume XV - Fall 2014 \\
\hline Law \& Policy & ISSN 2164-800X (online) \\
\hline Law & $\begin{array}{l}\text { DOI 10.5195/t|p.2014.154 } \\
\text { http://t|p.law.pitt.edu }\end{array}$ \\
\hline
\end{tabular}

\title{
China vs. United States: A Cosmopolitan Copyright \\ Comparison
}

Amy Rosen

\section{(cc) BY-NC-ND}

This work is licensed under a Creative Commons Attribution-Noncommercial-No Derivative Works 3.0 United States License.

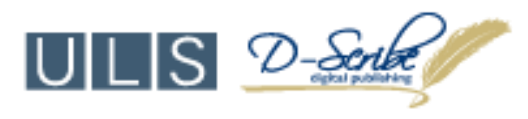

This site is published by the University Library System of the University of Pittsburgh as part of its DScribe Digital Publishing Program and is cosponsored by the University of Pittsburgh Press. 


\title{
China vs. United States: A Cosmopolitan Copyright Comparison
}

\author{
Amy Rosen*
}

\section{INTRODUCTION}

The notion "[t]hat China is a hotbed for piracy is nothing new,"1 but does this assumption hold true? It is true that the intellectual property system in China is a work in progress. ${ }^{2}$ It is also true that China has a long history of disregarding intellectual property rights ("IPR"), ${ }^{3}$ but a healthy debate remains as to whether the country has become more proactive in protecting intellectual property than the United States. ${ }^{4}$ The general understanding is that China does not protect intellectual property, but this assumption has been steadily changing. ${ }^{5}$ The standard view is that the concepts embedded within intellectual property law are too abstract and too foreign to Chinese citizens working in the judiciary and administrative branches ${ }^{6}$ because the notions of privacy and IPR are not valued in Chinese culture, resulting in a lack of protection for intellectual property. Yet, some have argued that China's actual protection of IPR does not align with this assumption, claiming that the

\footnotetext{
${ }^{*}$ Amy Rosen is an attorney admitted to practice law in Pennsylvania and New Jersey. She would like to thank her parents, Mark and Shirley Rosen, for everything they have done for me. Also, many thanks go to Professor Mo Zhang, Associate Professor of Law at Temple University Beasley School of Law, for his crucial academic support. 最谢谢您!

${ }^{1}$ Jason Subler, Insight: Fake Apple Store Cuts to Core of China Risk to Brands, REUTERS (July 22, 2011 8:51 AM), available at http://www.reuters.com/article/2011/07/22/us-china-applebrands-idUSTRE76L2K320110722.

${ }^{2}$ See Brian J. Safran, A Critical Look at Western Perceptions of China's Intellectual Property Regime, 3.2 U. P.R. BUS. L.J. 135, 179 (2012), available at http://www.uprblj.com/wp/wp-content/ uploads/2012/06/3.2-UPRBLJ-135-Brian-Safran-A-Critical-Look-at-Western-Perceptions-of-ChinasIntellectual-Property-System-06-01-2012.pdf.

${ }^{3}$ Xuan-Thao Nguyen, The China We Hardly Know: Revealing the New China's Intellectual Property System, 55 ST. LoUIS U. L.J. 773, 773 (2011).

${ }^{4} I d$.

${ }^{5}$ Michael J. Meagher \& Lucia Lian, Chinese Law for Lao Wai: A Survey of Chinese Law for American Business Lawyers, 51-Feb. B. B. J. 17, 19 (2007).

${ }^{6}$ Nguyen, supra note 3, at 774 (explaining that in communist China, with 1.3 billion people, "the concept of private property is not fully understood nor valued, let alone the abstract notion of intellectual property") (quoting Peter S. Goodman, Pirated Goods Swamp China: Official Crackdown has Little Effect, WASH. POST, Sept. 7, 2004, at E1).

Journal of Technology Law \& Policy
}

Volume XV - Fall 2014 • ISSN 2164-800X (online) DOI 10.5195/tlp.2014.154 $\bullet$ http://tlp.law.pitt.edu 
country is actually developing a stronger IPR regime. ${ }^{7}$ Others have suggested that the negative American perceptions of China's IPR regime discourage foreign businesses from even attempting to protect IPR in China, allowing them to continue to complain about its IPR regime. ${ }^{8}$ Developing an objective picture of IPR in China is essential in more accurately understanding China's actual protection of copyright, especially in comparison to the United States. ${ }^{9}$

Copyright law, a subset of intellectual property law, is important because it promotes the creation and protection of works of art such as books, music, performances, and movies. ${ }^{10}$ In China, counterfeiting and the piracy of goods remain relevant issues. ${ }^{11}$ It is well known that products such as bootleg DVDs are easy and cheap to acquire, much to the chagrin of the American film industry. ${ }^{12}$ Likewise, computer software is also pirated. ${ }^{13}$ In fact, one report estimates that the number of Chinese government computers running illegal copies of Microsoft Word could be at least 80 percent. $^{14}$ This is true despite a government order $^{15}$ that

${ }^{7}$ Id. at 775-76; see also Safran, supra note 2, at 137 (questioning whether "survey results truly reflect the business operating environment in China or whether they merely reflect the collective business consciousness and perception that, because of the amount and visibility of IP infringement in China, its IP regulatory and enforcement regime is weak").

${ }^{8}$ See Safran, supra note 2, at 146 (looking at the Theory of Reasoned Action (TRA) to explain how Western perceptions of the Chinese IP system may color U.S. perception although IP enforcement in China may actually be improving, and that negative views of China's IP system "are a product of ... individual attitudes and subjective norms which are drawn from the views and expectations of the larger business community").

${ }^{9} I d$. at 138 (stating that "[f]rom a corporate standpoint, it is imperative that the IP environment in China be analyzed objectively and free from subjective constraints from survey data presented").

${ }^{10}$ U.S. ConsT. art. I, $\S 8$ (stating that the purpose of the Copyright act is to "to promote the progress of science and useful arts").

${ }^{11}$ Peter K. Yu, The Middle Kingdom and the Intellectual Property World, 13 OR. REV. INT'L L. 209, 209-10 (2011).

${ }^{12}$ Dan Levin \& John Horn, DVD pirates running rampant in China, L.A. TiMES (Mar. 22, 2011), http://articles.latimes.com/2011/mar/22/entertainment/la-et-china-piracy-20110322.

${ }_{13}$ Grant Gross, China Orders PC Software Preload to Curb Piracy, IT WoRLD CANADA (Apr. 11, 2006), http://www.itworldcanada.com/news/china-orders-pc-software-preload-to-curb-piracy/ 98675; see also U.S.-China Trade Talks Achieve "Clear Progress," http://trade.gov/press/ publications/newsletters/ita_0406/jcct_0406.asp; see also Commitments Made by China in the U.S.China Joint Commission on Commerce and Trade (JCCT) (2004-2012), http://www.gao.gov/ special.pubs/gao-14-224sp/jcct_list.html.

${ }^{14}$ Robert D. Atkinson, Enough is Enough: Confronting Chinese Innovation Mercantilism, THE INFO. TECH. \& INNOVATION FOUND., 38, http://www2.itif.org/2012-enough-enough-chinesemercantilism.pdf (last modified Feb. 2012).

${ }^{15}$ Id.

Journal of Technology Law \& Policy

Volume XV - Fall 2014 • ISSN 2164-800X (online)

DOI 10.5195/tlp.2014.154 • http://tlp.law.pitt.edu 
attempted to curb piracy of computer software in China beginning in 2006. ${ }^{16}$ Notwithstanding these rampant normative views of China's intellectual property regime, or lack thereof, the People's Republic of China ("PRC") has reported that it in fact strengthened IPR in 2012, with the state copyright authorities shutting down at least 183 websites that committed intellectual property infringement and piracy over the Internet. ${ }^{17}$

This Article explores and compares copyright protection in the United States and China, focusing on the effectiveness of law and policy in both countries, and recommends potential solutions for improving copyright protection. Part I explores the similarities and differences between copyright laws in the United States and China. Specifically, this section discusses the purposes behind copyright law and what exclusive rights are afforded to works of authorship in both countries. Part II compares the two systems, concluding that the United States provides better protection to copyright owners. Part III analyzes three possible solutions as to how China can better protect copyright, settling on the proposal that China will have an incentive to more strictly monitor copyright infringement if it proves profitable, a solution that avoids the imposition of Western values.

\section{COPYRIGHT LAW IN THE UNITED STATES AND CHINA}

\section{A. Copyright Law in the United States}

Stemming from the U.S. Constitution, copyright law has a long history in the United States. ${ }^{18}$ The purpose of U.S. copyright law is "to Promote the Progress of Science and useful Arts, by securing for limited Times to Authors and Inventors the exclusive Right to their respective Writings and Discoveries." 19 A work of

\footnotetext{
16 Atkinson, supra note 14; see also David Lague, China Begins Effort to Curb Piracy of Computer Software, N.Y. TIMES (May 30, 2006), available at http://www.nytimes.com/2006/05/30/ technology/30soft.html (stating that "[o]n March 31, [2006,] Beijing announced that local computer makers must ship all their products with licensed operating systems pre-installed. The government has also started a drive to ensure that all computers in the country's sprawling bureaucracy are loaded with legitimate software.").

${ }^{17}$ China Handles More IPR Crimes in 2012, CHINA DAILY (Mar. 21, 2013, 5:28 PM), available at http://www.chinadaily.com.cn/china/2013-03/21/content_16331373.htm.

${ }^{18}$ U.S. CONST. art. I, $\S 8$, cl. 8 .

${ }^{19} I d$.

A COSM OPOLITA N COPYRIGH T COMPARISON
}

Volume XV - Fall 2014 • ISSN 2164-800X (online)

DOI 10.5195/tlp.2014.154 $\bullet$ http://tlp.law.pitt.edu 
authorship must conform to the requirements of the U.S. Copyright $\mathrm{Act}^{20}$ in order for the copyright owner to receive exclusive rights in the work. ${ }^{21}$

Copyright protection subsists "in original works of authorship fixed in any tangible medium of expression, now known or later developed, from which they can be perceived, reproduced, or otherwise communicated, either directly or with the aid of a machine or device." ${ }^{22}$ In order for a work of authorship to be considered original, the work must be an independent creation and have a modicum of creativity. ${ }^{23}$ Works of authorship include, but are not limited to, motion pictures, sound recordings, and literary, musical, dramatic, pictorial and architectural works. ${ }^{24}$ Copyright subsists at creation-when the work is capable of being reproduced - and endures for the life of the author plus seventy years. ${ }^{25}$

Copyright confers the exclusive rights to reproduce the work, ${ }^{26}$ to distribute copies of the work, ${ }^{27}$ to perform the work, ${ }^{28}$ to display the work publicly, ${ }^{29}$ and to broadcast the work publicly by means of a digital audio transmission. ${ }^{30}$ In addition, a copyright owner may not pursue certain legal remedies, such as actual or statutory damages and profits, ${ }^{31}$ for potential infringements of those rights until the work is registered with the United States Copyright Office. ${ }^{32}$ Once the work is registered, an owner may bring an infringement lawsuit if one of the owner's

${ }^{20}$ Copyright Act of 1976, Pub. L. No. 94-553, 90 Stat. 2541 (codified as amended in scattered sections of 17 U.S.C.).

${ }^{21} 17$ U.S.C. $\S 106(2012)$.

2217 U.S.C. § 102(a) (2012).

${ }^{23}$ Feist Publ’ns Inc. v. Rural Tel. Serv. Co., 499 U.S. 340, 346 (1991) (“" [t]he Court explained that originality requires independent creation plus a modicum of creativity. ...”).

${ }^{24} 17$ U.S.C. § 102(a)(1)-(8) (2012).

${ }^{25} 17$ U.S.C. § 302(a) (2012); see also Eldred v. Ashcroft, 537 U.S. 186 (2003) (stating that the Copyright term of the author's life plus seventy years was Constitutional).

${ }^{26} 17$ U.S.C. $§ 106(1)(2012)$.

${ }^{27} 17$ U.S.C. $\$ 106(3)$ (2012).

${ }^{28} 17$ U.S.C. $\S 106(4)$ (2012).

${ }^{29} 17$ U.S.C. $\S 106(5)$ (2012).

${ }^{30} 17$ U.S.C. § 106(6) (2012).

${ }^{31} 17$ U.S.C. $\$ 504$ (2012).

3217 U.S.C. $\S 411$ (a) (2012) (“' $[$ e]xcept for an action brought for a violation of the rights of the author under section $106 \mathrm{~A}(\mathrm{a})$, and subject to the provisions of subsection (b), no civil action for infringement of the copyright in any United States work shall be instituted until preregistration or registration of the copyright claim has been made in accordance with this title").

Journal of Technology Law \& Policy

Volume XV - Fall $2014 \bullet$ ISSN 2164-800X (online) DOI 10.5195/tlp.2014.154 • http://tlp.law.pitt.edu 
exclusive rights has been violated. ${ }^{33}$ Both published and unpublished works are protected under U.S. copyright law, regardless of the nationality or domicile of the author. ${ }^{34}$

\section{B. Copyright Law in China}

\section{History}

Copyright law in China can be traced back to the Imperial Age. ${ }^{35}$ However, China's treatment of intellectual property has dramatically shifted over the past 60 years. Under Chairman Mao Zedong's rule, China did not participate in the protection of international intellectual property primarily due to the emergence of isolationist policies after the establishment of the PRC in 1949. ${ }^{36}$ While Mao Zedong was in power, individual artistic expression had no value, and was only permitted to the extent that it embodied and supported state ideology. ${ }^{37}$ During this time, many intellectuals and writers were tortured and killed as a result of the antiintellectualism policies of the Cultural Revolution. ${ }^{38}$

Following Mao's death, however, China opened itself up for foreign trade, allowing authors to regain some intellectual property rights. ${ }^{39}$ Mao's successor, Deng Xiaoping, who rose to power in $1978,{ }^{40}$ sought to modernize agriculture,

${ }^{33} I d$.

${ }^{34} 17$ U.S.C. $\$ 104(a)$ (2013); but see 17 U.S.C. § 104(b)(1)(2) (2013) (stating that published works receive protection when "(1) on the date of first publication, one or more of the authors is a national or domiciliary of the United States, or is a national, domiciliary, or sovereign authority of a treaty party, or is a stateless person, wherever that person may be domiciled; or (2) the work is first published in the United States or in a foreign nation that, on the date of first publication, is a treaty party").

${ }^{35}$ Marc H. Greenberg, The Sly Rabbit and the Three C's: China, Copyright and Calligraphy, 7 LOY. U. CHI. INTL. L. REV. 163, 172-75 (2010) (discussing that Chinese copyright can be traced back to the Imperial Age beginning with the Qin (221-206 B.C.) through the Qing dynasty (A.D. 1644-1911)).

${ }^{36} \mathrm{Yu}$, supra note 11, at 215 ("During the Mao era, China made a similar mistake by withdrawing completely from the global economy. Practicing self-reliance and import substitution, China sought to produce domestically those products it traditionally imported.") (quoting Peter K. Yu, From Pirates to Partners: Protecting Intellectual Property in China in the Twenty-first Century, 50 AM. U. L. REv. 131, $198(2000))$.

${ }^{37}$ Jordana Cornish, Note, Cracks in the Great Wall: Why China's Copyright Law has Failed to Prevent Piracy of American Movies within its Borders, 9 VAND. J. ENT. \& TECH. L. 405, 414 (2006)

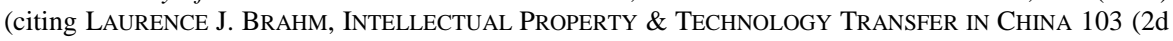
ed. 1994)).

${ }^{38}$ Greenberg, supra note 35, at 176.

${ }^{39} I d$. at 165.

${ }^{40}$ Safran, supra note 2, at 139.

A COSM OPOLITAN COPYRIGH T COMPARISON

Volume XV - Fall 2014 • ISSN 2164-800X (online)

DOI 10.5195/tlp.2014.154 $\bullet$ http://tlp.law.pitt.edu 
industry, science and technology, and national defense. ${ }^{41}$ Deng did this, in part, by adopting the Open Door Policy with the United States in $1978 .{ }^{42}$ This new policy encouraged the rapid enactment of laws as well as prompted new innovations in research and business. ${ }^{43}$ For example, during this period, China's economy shifted from a command to a market economy. ${ }^{44}$ After 1979, this shift promoted more IP protections, and as China developed an "IPR fever" it began researching IP for the sake of fostering local innovation and encouraging foreign investment. ${ }^{45}$ As a result of the "IPR fever," the Deng administration supported the creation of administrative agencies that handled registration of intellectual property works. ${ }^{46}$

Other countries have also heavily influenced China's copyright and intellectual property laws. Looking to foreign models, China sought to reconcile its legal system with international practices and norms. ${ }^{47}$ For example, the first intellectual property agreement between the United States and China was the Agreement on Trade Relations Between the United States of America and the People's Republic of China ("Trade Agreement") in 1979.48 The Trade Agreement recognized the "importance of effective protection of patents, trademarks, and copyrights." ${ }^{49}$ Shortly thereafter, in 1980, China became a World Intellectual

${ }^{41} I d$. at 138 (citing TAKAShi KANATSU, Asian Politics: Tradition, Transformation AND FUTURE 128 (2008)).

${ }^{42}$ Id. at 139 (citing KANATSU, supra note 41, at 142).

${ }^{43} I d$. at 139.

${ }^{44}$ Greenberg, supra note 35, at 179 (stating that "fundamental economic structure [had] been further transformed from a central planning system ('command economy') into a socialist market economy") (quoting Xiaoqing Feng \& Xianfeng Juang, International Standards and Local Elements: New Developments of Copyright Law in China, 49 J. COPYRIGHT SOC'Y U.S.A. 917 (2002)).

${ }^{45}$ Safran, supra note 2, at 139 (citing Deli Yang, The Development of the Intellectual Property in China (Bradford U. Sch. of Mgmt., Working Papers Series, Paper No. 2, 2002), at 8, http://www.brad .ac.uk/acad/management/external/pdf/workingpapers/Booklet_02-24.pdf; Agreement on Cooperation in Science and Technology (with Exchange of Letters), U.S.-China, Jan. 31, 1979, 1150 U.N.T.S. 18076; http://treaties.un.org/doc/Publication/UNTS/Volume\%201150/v1150.pdf; REBECCA ORDISH \& ALAN AdCock, China Intellectual Property - Challenges \& Solutions: An Essential Business GUIDE 6 (2008)).

${ }^{46}$ Safran, supra note 2, at 140 (citing ORDISH \& ADCOCK, supra note 45, at 7). (2009).

${ }^{47}$ Benjamin L. Liebman, Assessing China's Legal Reforms, 23 Colum. J. AsiAn L. 17, 30

${ }^{48}$ Yu, supra note 11, at 216 (citing the Agreement on Trade Relationships Between the United States of America and the People's Republic of China, U.S.-China, July 7, 1979, 31 U.S.T. 4652 [hereinafter 1979 Agreement]); Cornish, supra note 37, at 414 (citing Eric Priest, The Future of Music and Film Piracy in China, 21 BeRKeLEY TeCH. L.J. 795, 806 (2006)).

${ }^{49}$ Enforcement and Compliance: Agreement on Trade Relations Between the United States of America and the People's Republic of China, art. IV(1)(5), available at http://tcc.export.gov/ trade_agreements/all_trade_agreements/people_china.asp (stating that "[b]oth Contracting Parties agree

Journal of Technology Law \& Policy

Volume XV - Fall 2014 • ISSN 2164-800X (online)

DOI 10.5195/tlp.2014.154 $\bullet$ http://tlp.law.pitt.edu 
Property Organization (WIPO) member. ${ }^{50}$ The purpose of WIPO is to encourage the development of a balanced and effective intellectual property system that enables creativity for the benefit of all. ${ }^{51}$ In 1985, China also joined the Paris Convention, ${ }^{52}$ which provides standards for protecting trademarks and patents.

In 1990, China enacted its first Copyright Law, which was largely shaped by foreign pressure, especially from the United States Trade Representative ("USTR"). ${ }^{53}$ The United States wanted less piracy to occur in China, and sought to increase market access and profitability ${ }^{54}$ After the Copyright Law was enacted, China continued to establish subsequent IP protections..$^{55}$ For example, specialized Intellectual Property Tribunals have served as Chinese courts at the intermediate level or higher since $1993 .{ }^{56}$ In addition, since enacting the Copyright Law, China revised it in 2001, 2010, and, most recently, on March 31, 2012.57

\section{The Current State of Copyright Law in China}

The purpose of the Chinese Copyright Law differs from that of the United States Copyright Act. The Chinese Copyright Law is designed to protect literary, artistic, and scientific works and rights related to copyright, ${ }^{58}$ but it does so for the purposes of "building ... a socialist society that is advanced ethically and materially, and promoting the progress and flourishing of socialist culture and sciences. ${ }^{" 59}$ As with other areas of Chinese law, ${ }^{60}$ the Chinese government controls

that each Party shall take appropriate measures, under its laws and regulations and with due regard to international practice, to ensure to legal or natural persons of the other Party protection of copyrights equivalent to the copy right protection correspondingly accorded by the other Party").

${ }^{50} \mathrm{Yu}$, supra note 11, at 222 (citing Contracting Parties, WIPO, available at http://www.wipo.int/ treaties/en/ShowResults.jsp?lang=e\&treaty_id=1 (last visited Mar. 30, 2013)).

${ }^{51}$ Inside WIPO: What is WIPO?, available at http://www.wipo.int/about-wipo/en/ (last visited Sept. 9, 2014).

${ }^{52} \mathrm{Yu}$, supra note 11, at 217.

${ }^{53}$ Id. at 219 (citing Yu, supra note 36, at 141).

${ }^{54} I d$. at 250 .

${ }^{55}$ Safran, supra note 2, at 154 (quoting IPR Toolkit: Protecting your Intellectual Property Rights $(I P R)$ in China, EMBASSY OF THE UNITED STATES, BEIJING, CHINA, http://beijing.usembassychina.org.cn/protecting_ipr.html [hereinafter IPR Toolkit]).

${ }^{56} \mathrm{Id}$.

${ }^{57}$ Hong Xue, One Step Ahead, Two Steps Back: Reverse Engineering the Second Draft for the Third Revision of the Chinese Copyright Law, 28 AM. U. INT'L L. REV. 295, 295-96 (2012).

${ }^{58}$ China: Copyright Law of the People's Republic of China, WORLD INTELLECTUAL PROPERTY ORGANIZATION, http://www.wipo.int/wipolex/en/text.jsp?file_id=186569 (last updated Feb. 26, 2010) [hereinafter Copyright Law].

${ }^{59} I d$.

\section{A C OS M O P L I T A N C O P R I G H T O M P R I S N}

Volume XV - Fall $2014 \bullet$ ISSN 2164-800X (online)

DOI 10.5195/tlp.2014.154 • http://tlp.law.pitt.edu 
which works receive copyright protection based on whether or not the work promotes or advances this purpose. ${ }^{61}$ Thus, the overall purpose of Chinese copyright law differs from the general purpose of intellectual property law in the United States, as U.S. copyright law promotes invention and expression, rather than a particular governmental agenda. ${ }^{62}$ The Chinese Copyright Law also empowers the State to supervise and administer "the publication and dissemination of works." ${ }^{63}$ In the United States, however, the federal government does not have the constitutional authority to do so. ${ }^{64}$

China's Copyright Law was initially shaped by foreign pressure, and as such, foreign authors actually received greater protection than Chinese citizens ${ }^{65}$ but this trend has changed over the past twenty years. Similar to the U.S. Copyright Act, "works" under China's Copyright Law include photographs, cinematographic works, drawings, written works, and audio works. ${ }^{66}$ Today, for Chinese citizens, works do not need to be published in order to receive copyright protections, ${ }^{67}$ but foreigners can only acquire copyright protections if and when their work is first published in China. ${ }^{68}$ Dissimilarly, citizenship and publication in the United States is not required for protection under the U.S. Copyright Act. ${ }^{69}$

${ }^{60}$ Contract Law (promulgated by the Second Session of the Ninth Nat'1 People's Cong., Mar. 15, 1999, effective Oct. 1, 1999) art. 7 (1999) (China) (stating that "in concluding or performing a contract, the parties shall abide by the relevant laws and administrative regulations, as well as observe social ethics, and may not disrupt social and economic order or harm the public interests").

${ }^{61}$ Copyright Law, supra note 58.

${ }^{62}$ THe Federalist, No. 43 (James Madison) (stating that, regarding the Copyright Clause, "[t]he utility of this power will scarcely be questioned. The copyright of authors has been solemnly adjudged, in Great Britain, to be a right of common law. The right to useful inventions seems with equal reason to belong to the inventors. The public good fully coincides in both cases with the claims of individuals. The States cannot separately make effectual provisions for either of the cases, and most of them have anticipated the decision of this point, by laws passed at the instance of Congress").

${ }^{63}$ Copyright Law, supra note 58, at art. 4.

${ }^{64}$ See U.S. CONST. art. I, § 8.

${ }^{65}$ Robert S. Rogoyski \& Kenneth Basin, The Bloody Case that Started from a Parody: American Intellectual Property and the Pursuit of Democratic Ideals in Modern China, 16 UCLA ENT. L. REV. 237, 250 (2009) (citing ANDrew C. Mertha, Policies of Piracy: InTellectual Property in CONTEMPORARY CHINA 118-19 (2007)).

${ }^{66}$ Copyright Law, supra note 58, at art. 3.

${ }^{67} I d$. at art. 2.

${ }^{68} I d$.

${ }^{69} 17$ U.S.C. $§ 104(a)$ (2012); see also 17 U.S.C. § 104(b)(1)-(2) (2012) (stating that published works receive publication "(1) on the date of first publication, one or more of the authors is a national or domiciliary of the United States, or is a national, domiciliary, or sovereign authority of a treaty party, or

Journal of Technology Law \& Policy

Volume XV - Fall 2014 • ISSN 2164-800X (online)

DOI 10.5195/tlp.2014.154 $\bullet$ http://tlp.law.pitt.edu 
Chinese copyright holders have a variety of exclusive rights for their copyrighted works. ${ }^{70}$ The owner has the right of publication, ${ }^{71}$ authorship, ${ }^{72}$ revision ${ }^{73}$ integrity, ${ }^{74}$ reproduction, distribution, rental, exhibition, translation, compilation, and any other rights the copyright owner is entitled to enjoy. ${ }^{75}$ Copyright extends to works that are expressed as:

(1) written works; (2) oral works; (3) musical, dramatic, quyi, choreographic and acrobatic works; (4) works of fine art and architecture; (5) photographic works; (6) cinematographic works; (7) graphic works such as drawings of engineering and product designs; (8) maps, sketches, and other graphic and model works; (9) computer software; and (10) other works. ${ }^{76}$

Generally, certain types of reproductions are allowed unless the author declares that use of his or her work is not permitted. ${ }^{77}$ The copyright in China lasts for the author's life plus fifty years. ${ }^{78}$

Enforcement of IPR in China falls within its judicial and administrative branches. ${ }^{79}$ China has intellectual property enforcement agencies within its own

is a stateless person, wherever that person may be domiciled; or (2) the work is first published in the United States or in a foreign nation that, on the date of first publication, is a treaty party").

${ }^{70}$ Safran, supra note 2, at 148-49.

71 Copyright Law, supra note 58, at art. 10(1) ("the right to decide whether to make a work available to the public").

${ }^{72} \mathrm{Id}$. at art. 10(2) ("the right to claim authorship in respect of, and to have the author's name mentioned in connect with, a work").

${ }^{73} I d$. at art. 10(3) ("the right to revise or authorize others to revise a work").

${ }^{74} I d$. at art. 10(4) ("the right to protect a work against distortion and mutilation").

${ }^{75}$ Id. at art. 10(5)-(17); Heidi Hansen Kalscheur, Note, About "Face”: Using Moral Rights to Increase Copyright Enforcement in China, 39 HASTINGS ConsT. L.Q. 513, 519 (2012) (listing that rights including in copyright are (1) publication; (2) authorship; (3) revision; (4) integrity; (5) reproduction; (6) distribution; (7) rental; (8) exhibition; (9) performance; (10) presentation; (11) broadcasting; (12) communication of information on networks; (13) making cinematographic work; (14) adaptation; (15) translation; (16) compilation; and (17) any other rights copyright owner is entitled to enjoy").

${ }^{76}$ Kalscheur, supra note 75 , at 519.

${ }^{77}$ Copyright Law, supra note 58, at art. 22(1)-(12); art. 23.

${ }^{78}$ Id. at art. 21.

A COSM OPOLITA N COPYRIGH T COMPARISON

Volume XV - Fall $2014 \bullet$ ISSN 2164-800X (online)

DOI 10.5195/tlp.2014.154 $\bullet$ http://tlp.law.pitt.edu 
judicial system. ${ }^{80}$ The agencies that can impose penalties for copyright infringement are the National Copyright Administration (NCA) and the State Administration for Industry and Commerce (SAIC) ${ }^{81}$ While the NCA generally handles cases of nationwide importance, the SAIC handles more localized cases. ${ }^{82}$

Copyright infringement complaints must follow certain administrative procedures in China. To begin, a copyright holder must submit an administrative complaint for copyright infringement. ${ }^{83}$ In the case of a company, the complaint must include the following information: "(1) the name and provision of its legal representative; (2) proper documentation to establish copyright ownership; (3) a sample or copy of the infringing work; (4) a claim for compensation; (5) a factual description of the infringement; and (6) documentary evidence, to include names and addresses of witnesses." ${ }^{84}$ Once the complaint has been received, the agency will decide whether to reject or accept it. ${ }^{85}$ If the complaint is accepted, the agency "will designate at least two (2) law enforcement officers to investigate the underlying claims, collect and review evidence, seize the infringing products, and review witnesses." ${ }^{186}$ After completing the investigation, the officers will write a Copyright Administrative Penalty Opinion, recommending a penalty and giving the alleged infringer the right to respond ${ }^{87}$ The penalty will stand unless the infringing party responds within three days. ${ }^{88}$ The penalty may include "sanctions such as administrative fines, injunctions, revocations of business licenses, confiscation of machinery used to produce the infringing goods, or the referral of the infringing party for criminal prosecution." 89

${ }^{79}$ Kalscheur, supra note 75, at 519 (citing Yu Zingzhong, Western Constitutional Ideas and Constitutional Discourse in China 1978-2005, in BUILDING Constitutionalism IN China 66 (Stephanie Balme \& Michael Dowdle eds., 2009)).

${ }^{80}$ Safran, supra note 2, at 159 (quoting IPR Toolkit, supra note 55).

${ }^{81} \mathrm{Id}$.

${ }^{82} \mathrm{Id}$.

${ }^{83}$ Id. at 159-60 (citing IPR Toolkit, supra note 55).

${ }^{84} \mathrm{Id}$.

${ }^{85} \mathrm{Id}$.

${ }^{86} \mathrm{Id}$.

${ }^{87}$ Safran, supra note 2, at 160 (citing IPR Toolkit, supra note 55).

${ }^{88} \mathrm{Id}$.

${ }^{89} \mathrm{Id}$.

\begin{tabular}{l} 
Journal of Technology Law \& Policy \\
\hline
\end{tabular}

Volume XV - Fall 2014 • ISSN 2164-800X (online)

DOI 10.5195/tlp.2014.154 $\bullet$ http://tlp.law.pitt.edu 
China also has criminal measures in force to deal with violations of IPR..$^{90}$ The country's criminal law provides for penalties in "serious circumstances," which are defined as "reproducing or distributing 500 or more unauthorized copies or deriving profits in excess of 50,000 yuan." 91 The second amended Copyright Law allows for "semi-statutory damages of up to RMB 1 million (USD \$156,799) where the rights holder's actual loss, infringer's illegal gains, or usual right transaction fees cannot be determined." ${ }^{92}$ Moreover, a court has discretion to determine damages, and repeat infringers may have to pay "seemingly punitive damages. ${ }^{93}$

\section{Which COUNTRY BetTer PROTECTS COPYRIGHT?}

\section{A. Copyright Infringement Cases as Evidence of IPR Protection}

One method for examining which country protects copyrights more effectively is by going beyond the letter and purpose of each country's law and looking at the number of litigated cases. As a general trend, in the United States, the number of copyright cases has remained steady over the past eight years, from 2,084 copyright cases in 2002 to 2,013 copyright cases in $2010 .{ }^{94}$ But in 2013, the number of copyright cases jumped 48 percent to $3,553 .{ }^{95}$

The number of copyright infringement cases in China paints a different picture of its IPR protection than what many may assume, and end up following a trend similar to the United States. ${ }^{96}$ In fact, despite the continued dissatisfaction of the United States government and its rights holders, improvements over the past

${ }^{90}$ Kevin C. Lacey, China and the WTO: Targeting China's IPR Record, LANDSLIDE, Jan./Feb. 2012 , at 33,36 .

${ }^{91} I d$.

${ }^{92}$ Xue, supra note 57 , at 307.

${ }^{93} \mathrm{Id}$.

${ }^{94}$ Nguyen, supra note 3, at 785 (citing ADMIN. OfFICE OF THE U.S. COURTS, TABLE 4.7: COPYRIGHT, PATENT, AND TRADEMARK CASES FILED (2007), available at http://www.uscourts.gov/ uscourts/Statistics/JudicialFactsAndFigures/2007/Table407.pdf) (more specifically, in 2002 there were 2,084 copyright cases, which increased to 2,448 cases in 2003, increased to 3,007 cases in 2004, increased to 5,796 cases in 2005 , decreased to 4,944 cases in 2006 , and decreased to 4,400 cases in 2007).

${ }^{95}$ Caseload Statistics Summary, UnITED STATES COURTS (last visited Dec. 2, 2014), available at http://www.uscourts.gov/Statistics/FederalJudicialCaseloadStatistics/caseload-statistics-2013/caseloadsummary.aspx.

${ }^{96}$ Nguyen, supra note 3, at 809.

A COSM OPOLITA N COPYRIGH T COMPARISON

Volume XV - Fall 2014 • ISSN 2164-800X (online)

DOI 10.5195/tlp.2014.154 $\bullet$ http://tlp.law.pitt.edu 
two decades have been quite significant. ${ }^{97}$ During a seven-year period in China, first-instance copyright litigation cases increased significantly from 2,491 cases in $2003^{98}$ to 35,185 in $2011 .{ }^{99}$ In 2012 , Chinese courts received 87,419 intellectual property civil cases, which was a 45.99 percent increase from the previous year. ${ }^{100}$

However, although the number of 87,419 litigated copyright cases seems optimistic on its face, there may be a problem with these statistics. It has been speculated that "the Chinese government may be intentionally boosting the statistical data when it comes to domestic IP filings to show the world that Chinese companies are becoming increasingly innovative." 101 Adding to the uncertainty is the "[l]ack of transparent information on [intellectual property rights] infringement levels and enforcement activities," a problem that remains ongoing. ${ }^{102}$ Therefore, the numbers that China reports may be inaccurate or insufficient to determine whether China is actually improving its IPR regime.

Other authors have countered that China is in fact effectively protecting intellectual property. ${ }^{103}$ Professor Peter K. $\mathrm{Yu}^{104}$ stated that China's treaty membership shows that it is a "good citizen" in the international intellectual property regime. ${ }^{105}$ Professor Xuan-Thao Nguyen ${ }^{106}$ argues that the statistics from

${ }^{97}$ Peter K. Yu, Intellectual Property and Asian Values, 16 MARQ. INTELL. Prop. L. ReV. 329, 345 (2012).

${ }^{98}$ Nguyen, supra note 3, at 794.

${ }^{99}$ Sup. People's Ct., Intellectual Property Protection (Apr. 19, 2012), http://www.chinesemission -vienna.at/eng/xw/t924422.htm.

${ }^{100}$ China Issues White Paper on Intellectual Property Protection, China BRIEFING (Apr. 29, 2013), http://www.china-briefing.com/news/2013/04/29/china-issues-white-paper-on-intellectualproperty-protection.html. Information regarding the number of copyright cases filed in China was unavailable for 2013 and 2014.

${ }^{101}$ Safran, supra note 2, at 170-71.

${ }^{102}$ Cornish, supra note 37, at 429 (citing United States Trade Representative, 2005 Special 301 Report: Results of Out-of-Cycle Review on China (2005), http://www.ustr.gov/archive/assets/ Document_Library/Reports_Publications/2005/2005_Special_301/asset_upload_file195_7636.pdf).

${ }^{103}$ See generally Nguyen, supra note 3; Yu, supra note 11.

${ }^{104}$ Kern Family Chair in Intellectual Property Law and Director of the Intellectual Property Law Center at Drake University Law School.

${ }^{105} \mathrm{Yu}$, supra note 11, at 223 (stating that "as far as treaty membership is concerned, China is not a rogue player but rather a good citizen in the international intellectual property regime").

${ }^{106}$ Professor of Law at Southern Methodist University Dedman School of Law and expert in intellectual property law.

Journal of Technology Law \& Policy

Volume XV - Fall 2014 • ISSN 2164-800X (online)

DOI 10.5195/tlp.2014.154 • http://tlp.law.pitt.edu 
2003-2007 demonstrate that China protects intellectual property better than the United States. ${ }^{107}$

Despite the foregoing, numbers are not everything. The mere fact that a judiciary handles more copyright-related cases does not mean that copyright is being protected more efficiently. Eighty-seven thousand litigated cases would be a high number if the total number of infringements was 90,000 , but 87,000 would be a small number if the infringing activity totaled 1,000,000. Since the baseline number of infringements in both countries is unknown, it is difficult to determine the levels of efficiency or effectiveness for these judicial mechanisms, or if they in fact have any deterrent effects.

Another problem with relying on the increasing lawsuit numbers as proof of improved IPR protection is that the number of foreigners who are pursuing copyright lawsuits in China is extremely low. For example, cases brought by foreign litigants comprised only 2.5 percent of intellectual property cases in 2006. ${ }^{108}$ Most foreign businesses do not even try to register their works or enforce IPR in China. ${ }^{109}$ The April 2011 White Paper ${ }^{110}$ issued by China's Supreme Court reported only 3.28 percent foreign litigants in IP-related cases. ${ }^{111}$ Even though "foreign IPR-holders have an easier time winning IP cases through the Chinese courts than do domestic IPR holders," 112 China still has a reputation for being the "Wild West of intellectual property piracy." 113 Despite the increased number of lawsuits, other factors suggest that China still grants a lower level of intellectual property protection than the United States.

\section{B. Other Factors Evidencing IPR Protection or Lack Thereof}

The continued pressure on China to strengthen its IPR regime demonstrates that its present copyright law and policy insufficiently protect businesses from

107 See Nguyen, supra note 3, at 773, 791-97.

${ }^{108}$ Id. at 797 (citing MINISTRY OF COMMERCE OF CHINA, REPORT ON CHINA's INTELLECTUAL PROPERTY PROTECTION IN 2006 (2007), available at http://www.chinaipr.gov.cn/policyarticle/ policy/documents/200706/236401_1.html) (reporting that among the 14,219 total intellectual property cases decided by the judicial system, only 353 cases involved foreign intellectual property owners).

${ }^{109}$ Safran, supra note 2, at 141.

${ }^{110}$ Id. (citing Supreme PeOPle's Court of China, InTEllectual Property Protection By ChInese CoURTs IN 2010 (China Pat. Agent, White Paper, 2011), available at http://www.cpahkltd .com/UploadFiles/20110509082512655.pdf).

${ }^{111}$ Id.

112 Id. at 175 (citing Interview with Shenjun Chen, Attorney with the Shanghai Patent \& Trademark Law Office (June 25, 2010)).

${ }^{113}$ Rogoyski \& Basin, supra note 65 , at 252.

A COSMOPOLITAN COPYRIGHT COMPARISON

Volume XV - Fall 2014 • ISSN 2164-800X (online)

DOI 10.5195/tlp.2014.154 $\bullet$ http://tlp.law.pitt.edu 
suffering financial loss. Both the United States and the World Trade Organization ("WTO") still acknowledge IP protection problems in China. This was noted, for instance, in a recent WTO Panel report. ${ }^{14}$ Specifically, the Panel found that the Chinese Copyright Law (prior to the 2010 revision) was inconsistent under Article 9.1 and 41.4 of the Agreement on Trade-Related Aspects of Intellectual Property Rights ("TRIPS"). ${ }^{115}$ According to the WTO ruling, China must "provide adequate copyright protection to the works for which government approval is pending or denied." ${ }^{116}$ The United States celebrated this ruling as a major victory. ${ }^{117}$ Unfortunately, scholars warn that it may not immediately change copyright protection in China. ${ }^{118}$ Furthermore, the WTO ruling was not a total success as the Panel did not directly say that China's criminal measures were inadequate for IPR protection. ${ }^{119}$

In 2011, U.S. President Barack Obama urged Chinese President Hu Jintao to increase the enforcement of domestic intellectual property in China. ${ }^{120}$ In addition, "private sector reports contend that a 50 percent decrease in Chinese software piracy could lead to an increase of $\$ 4$ billion in software sales for U.S. companies." 121 Consequently, infringement in China remains a serious business problem for American companies. Europeans also contend that the poor enforcement of copyright laws in China negatively affects their ability to conduct business within its borders. ${ }^{122}$ When surveyed, 44 percent of Europeans recognized that the discretionary enforcement of broadly drafted laws and regulations in China was a significant obstacle in doing business there. ${ }^{123}$ As such, China still faces huge

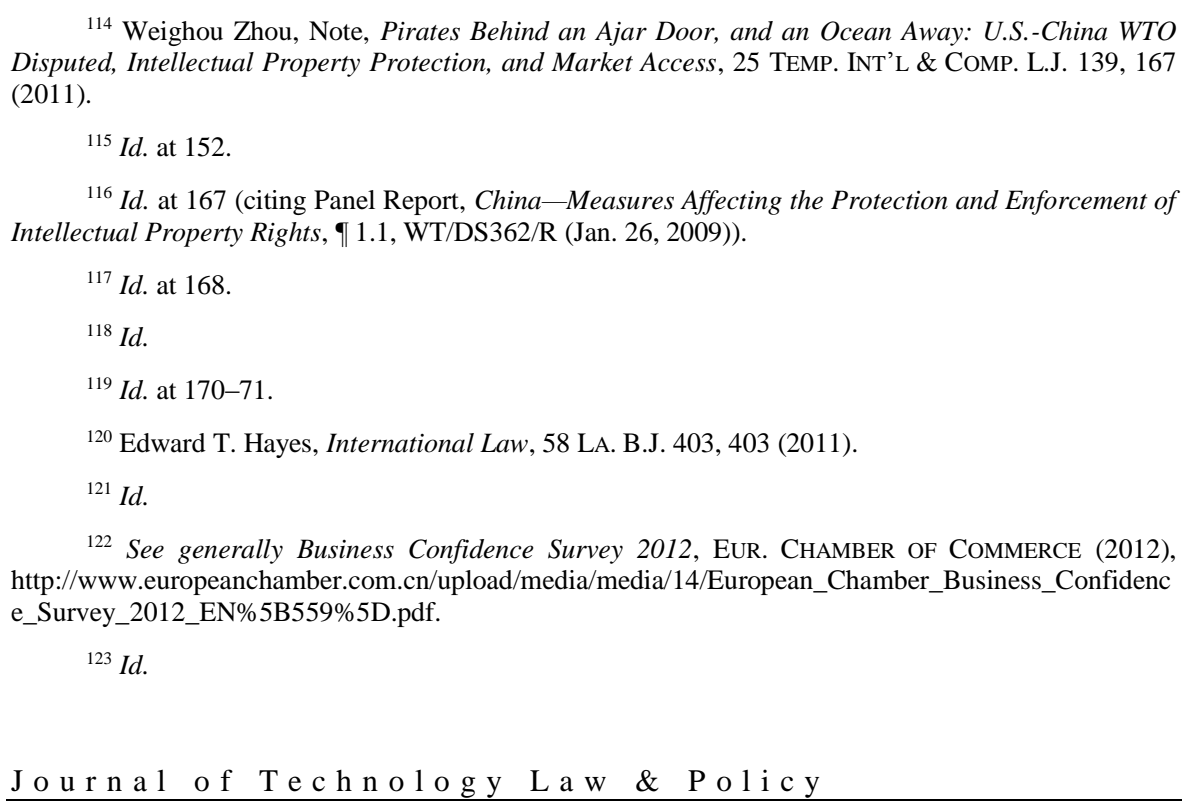

Volume XV - Fall 2014 • ISSN 2164-800X (online) DOI 10.5195/tlp.2014.154 $\bullet$ http://tlp.law.pitt.edu 
criticism from the political spheres and from media for mass copyright infringement. ${ }^{124}$

Attempts to use Western-style copyright procedures have been mostly unsuccessful in China. ${ }^{125}$ The United States has become frustrated with poor Chinese enforcement ${ }^{126}$ and has used the USTR to investigate Chinese IPR enforcement. ${ }^{127}$ The USTR is enabled, through $\S 301$ of the Trade Act of 1974, ${ }^{128}$ to initiate investigations when foreign governments are not adhering to trade agreements. ${ }^{129}$ If a foreign government's actions are unjustifiable, unreasonable, or discriminatory, and burden or restrict U.S. commerce, then the foreign government's acts are actionable under $\S 301 .{ }^{130}$ Through a $\S 301$ action, the USTR can investigate practices, and later must provide Congress with a list of countries that deny IPR protections to American companies in either patent, copyright, or trademark rights. ${ }^{131}$ Part of the USTR's report is to create a Priority Watch List for countries that do not properly protect intellectual property. ${ }^{132}$ In these annual

${ }^{124}$ Greenberg, supra note 35, at 172.
${ }^{125} I d$. at 164 .
${ }^{126}$ Id. at 178 ; Peter K. Yu, From Pirates to Partners (Episode II): Protecting Intellectual Property in Post-WTO China, 55 AM. U. L. REv. 901, 903 (2006); Zhou, supra note 114, at 139; Nguyen, supra note 3, at 788 (stating that in 2005 the USTR put "China on the 'Priority Watch List' because it had 'serious concerns' about China's compliance with its obligations under various agreements relating to intellectual property" (citing Bureau of Intl'1 Info. Programs U.S. Dep't of State, U.S.: China Has High Rate of Intellectual Property Infringement, America.gov (Apr. 29, 2005), http://iipdigital.usembassy.gov/st/english/texttrans/2005/04/20050429155355mbzemog0.5231745.html\# axzz2j8ykSwNr)).

${ }^{127}$ Greenberg, supra note 35, at 178; Yu, supra note 126, at 903; Zhou, supra note 114; Nguyen, supra note 3, at 788 (stating that in 2005 the USTR put "China on the 'Priority Watch List' because it had 'serious concerns' about China's compliance with its obligations under various agreements relating to intellectual property" (citing Bureau of Intl'l Info. Programs U.S. Dep't of State, U.S.: China Has High Rate of Intellectual Property Infringement, America.gov (Apr. 29, 2005), http://iipdigital .usembassy.gov/st/english/texttrans/2005/04/20050429155355mbzemog0.5231745.html\#axzz2j8ykSwN r)).

12819 U.S.C. $\S 2451$ (2012).

${ }_{129}$ Section 301, available at http://www.trade.gov/mas/ian/tradedisputes-enforcement/tg_ian_ 002100.asp; see Judith Hippler Bello, Section 301 of the Trade Act of 1974: Requirements, Procedures, and Developments, 7 Nw. J. INT'L L. \& Bus. 633 (1986).

${ }^{130} I d$.

${ }^{131} I d$.

${ }^{132}$ Greenberg, supra note 35, at 178; Yu, supra note 126, at 903; Zhou, supra note 114; Nguyen, supra note 3, at 788 (stating that in 2005 the USTR put "China on the 'Priority Watch List' because it had 'serious concerns' about China's compliance with its obligations under various agreements relating to intellectual property" (citing Bureau of Intl'l Info. Programs U.S. Dep't of State, U.S.: China Has High Rate of Intellectual Property Infringement, America.gov (Apr. 29, 2005), http://iipdigital

\section{A C OS M O P L I T A N C O P R I G H T C M P A R S O N}

Volume XV - Fall $2014 \bullet$ ISSN 2164-800X (online)

DOI 10.5195/tlp.2014.154 $\bullet$ http://tlp.law.pitt.edu 
reports, China was on the USTR's Priority Watch List for intellectual property violations in $2005,,^{133} 2006,{ }^{134} 2007,,^{135} 2008,{ }^{136} 2009,{ }^{137} 2010,{ }^{138} 2011,{ }^{139} 2012,{ }^{140}$ $2013,{ }^{141}$ and 2014. ${ }^{142}$

The United States has other safeguards that attempt to protect American companies from infringement in China. Section 421 of the 1974 Trade Act $^{143}$ is the mechanism the United States has sought to use to remedy China's lack of effective enforcement. ${ }^{144}$ The purpose behind $\S 421$ is to protect American companies when China fails to comply with WTO obligations. ${ }^{145}$ It allows the United States to impose safeguards "that are not subject to the WTO Agreement on Safeguards on

.usembassy.gov/st/english/texttrans/2005/04/20050429155355mbzemog0.5231745.html\#axzz2j8ykSwN r)).

${ }^{133}$ Bureau of Intl'1 Info. Programs U.S. Dep't of State, U.S.: China Has High Rate of Intellectual Property Infringement, America.gov (Apr. 29, 2005), http://www.america.gov/st/washfile-english/ 2005/april/20050429155355mbzemog0.5231745.html.

${ }^{134}$ United States Trade Representative, 2006 Special 301 Report: Priority Watch List (Apr. 28, 2006), available at http://www.keionline.org/sites/default/files/ustr_special301_2006.pdf.

${ }^{135}$ United States Trade Representative, 2007 Special 301 Report: Priority Watch List (Apr. 1, 2007), available at http://www.ustr.gov/sites/default/files/2007-301-PRIORITY\%20WATCH\% 20LIST.pdf.

${ }^{136}$ United States Trade Representative, 2008 Special 301 Report: Priority Watch List, available at http://www.ustr.gov/sites/default/files/asset_upload_file558_14870.pdf.

137 United States Trade Representative, 2009 Special Report: Section II: Country Reports (Apr. 30, 2009), available at http://www.ustr.gov/sites/default/files/Priority\%20Watch\%20List.pdf.

${ }^{138}$ United States Trade Representative, 2010 Special 301 Report, 19 (Apr. 30, 2010), available at http://www.ustr.gov/webfm_send/1906.

${ }^{139}$ United States Trade Representative, 2011 Special Report: Priority Watch List, available at http://www.ustr.gov/webfm_send/2849.

${ }^{140}$ United States Trade Representative, 2012 Special 301 Report (Apr. 2012), available at http://www.ustr.gov/sites/default/files/2012\%20Special\%20301\%20Report_0.pdf.

${ }^{141}$ United States Trade Representative, 2013 Special 301 Report (May 2013), available at http://www.ustr.gov/sites/default/files/05012013\%202013\%20Special\%20301\%20Report.pdf.

${ }_{142}$ United States Trade Representative, 2014 Special 301 Report (Apr. 2014), available at http://www.ustr.gov/sites/default/files/USTR\%202014\%20Special\%20301\%20Report\%20to\%20 Congress\%20FINAL.pdf.

14319 U.S.C. $§ 2451$ (2012).

${ }^{144}$ Michael W. Bouts, Note, Section 421: China's WTO Noncompliance and the Protection of U.S. Corporate Interests, 38 J. CORP. L. 139, 140 (2012).

${ }^{145} \mathrm{Id}$.

Journal of Technology Law \& Policy

Volume XV - Fall $2014 \bullet$ ISSN 2164-800X (online) DOI 10.5195/tlp.2014.154 $\bullet$ http://tlp.law.pitt.edu 
Chinese exports to the United States." ${ }^{146}$ Following an International Trade Commission ("ITC") investigation, the President can either decline to take action or impose three-year safeguards based on the ITC's recommendation. ${ }^{147}$

Overall, despite the higher number of litigated cased as compared to the United States, domestic and international IP procedures may not be effective, and China is not properly protecting copyright but seems to have legitimate reasons for failing to do so. Reports from China reveal that piracy operates as a separate business model, and that making, buying, and stealing intellectual property are all considered legitimate types of business models in China. ${ }^{148}$ Counterfeit products that are exported from China are assessed at approximately $\$ 60$ billion per year. ${ }^{149}$ "While the Chinese government has repeatedly promised to improve its enforcement capabilities, actual enforcement of [IPR] within China continues to be lackluster at best, particularly in the realm of criminal prosecutions." 150

There are several ideological considerations which help contextualize China's actions: 1) China is doing what the United States did during its developing stages, 2) intellectual property is a form of Western imperialism, and 3) China is still a developing country and learning how to become a better market economy. ${ }^{151}$ But rather than simply providing justifications for China's behavior, it is more important to focus on potential solutions for how to improve China's protection of IPR.

\section{WHAT'S NEXT?}

There are three possible solutions to the problems with Chinese copyright protection. The first solution is to encourage an independent judiciary to properly conduct copyright lawsuits, focusing on some of the procedural issues that make Chinese legal proceedings problematic. The second solution is to use elements of

${ }^{146}$ Id. at 148 (citing Jeanne J. Grimmett, Cong. Research Serv., R40844, Chinese Tire Imports: Section 421 Safeguards and the World Trade Organization (WTO) 8 (2001), available at http:www.fas .org/sgp/crs/misc/R40844.pdf).

${ }^{147} I d$. at 150 (citing 19 U.S.C. § 2451(k) (2012); 19 U.S.C. § 2451(o) (2012); 19 U.S.C. $\S 2435$ (b) (2012)).

${ }^{148}$ Atkinson, supra note 14, at 38.

${ }^{149}$ Nguyen, supra note 3, at 787 (citing Shaun Rein, How to Win the China Piracy Battle, BLOOMBERG.COM (June 20, 2007, 7:28 AM). http://www.businessweek.com/globalbiz/content/jun2007/ gb20070620_006304.htm).

${ }^{150}$ Lacey, supra note 90 , at 33.

${ }^{151}$ Atkinson, supra note 14, at 9, available at http://www2.itif.org/2012-enough-enough-chinesemercantilism.pdf.

A COSM OPOLITA N COPYRIGH T COMPARISON

Volume XV - Fall 2014 • ISSN 2164-800X (online) DOI 10.5195/tlp.2014.154 • http://tlp.law.pitt.edu 
Chinese culture to "re-educate" its population about the importance of intellectual property and why it should be protected. Both the first and second solutions require China to change internally; however, this seems unrealistic in light of China's strict system of government. ${ }^{152}$ Unlike the first two, the third solution does not impose Western values upon China, but instead characterizes change in light of a costbenefit analysis. More specifically, the third solution describes how to make copyright enforcement profitable for Chinese individuals and businesses. If Americans become interested in Chinese intellectual property, then a new revenue stream will be created, likely spurring additional intellectual property protections in China. The third solution is the most realistic proposal because it does not force China to submit to foreign pressures.

\section{A. An Independent Chinese Judiciary}

The first solution to improve copyright protection is to have an independent and properly trained Chinese judiciary. This judiciary would rule on IPR cases and also address some procedural issues involved in litigating those cases. Although Jiang Zhipei, Chief Justice of the Intellectual Property Rights Tribunal of the Chinese Supreme People's Court, has said that “'[f] oreign companies should take their complaints to the courts rather than to the newspapers or their politicians' and 'should complain less and act more,"”153 the Chinese judiciary and administrative agencies are fraught with problems. China's faulty judicial system must be remedied in order for copyright to receive meaningful protection in Chinese courts. ${ }^{154}$ However, local governmental officials, rather than the judiciary, could also be the cause of copyright problems. Specifically, "[l]ocal protectionism poses a major obstacle in combating ... piracy since provincial governments have the task of enforcing the copyright laws at the local level." 155 As will be discussed below, although there are Intellectual Property Tribunals and IP administrative agencies, having an independent judiciary may legitimize tribunal and agency decisions as the copyright cases in Chinese court systems increase. This legitimacy may also encourage foreigners to try to enforce their IPR through the courts in China.

\footnotetext{
${ }^{152}$ See Section A and B supra discussing these solutions.

${ }^{153}$ Safran, supra note 2, at 182 (citing ORDISH \& ADCOCK, supra note 45, at 182).

${ }^{154}$ Cornish, supra note 37 , at 433 .

${ }^{155}$ Id. at 430 (citing Brent T. Yonehara, Comment, Enter the Dragon: China's WTO Accession, Film Piracy and Prospects for the Enforcement of Copyright Laws, 9 UCLA ENT. L. REV. 389, 414-15 (2002)).

Journal of Technology Law \& Policy

Volume XV - Fall $2014 \bullet$ ISSN 2164-800X (online) DOI 10.5195/tlp.2014.154 $\bullet$ http://tlp.law.pitt.edu
} 
Fundamentally, the judicial branch lacks independence, ${ }^{156}$ and, furthermore, does not adhere to the principle of stare decisis. ${ }^{157}$ The difficulty with this lies in the fact that ex-parte influences are rampant and even expected. ${ }^{158}$ Chinese judges tend to have very little formal training and serve as political appointees, two factors that likely contribute to them being easily influenced. ${ }^{159}$

Despite having specific Intellectual Property Tribunals, ${ }^{160}$ the judges in China's legal system lack experience and expertise in intellectual property cases. ${ }^{161}$ The lack of formal training "is particularly problematic in China's inquisitorial judicial system where judges must determine the facts themselves rather than supervise adversarial lawyers' presentation of the story." ${ }^{162}$ However, major cities use specialized tribunals to hear certain intellectual property matters. ${ }^{163}$ Courts in these areas necessarily have more experience and expertise adjudicating intellectual property disputes. ${ }^{164}$

Regardless of their greater expertise, courts and agencies in major cities are still affected by corruption, receiving criticism for "selling out" to the highest bidder. ${ }^{165}$ If judges are prone to bribery, and lack the formal training and legal knowledge to understand complex copyright issues, then the 87,419 litigated

${ }^{156}$ Amy Rosen, Chinese Contract Formation: The Roles of Confucianism, Communism, and International Influences, 20 U. MiAmi INT'L \& COMP. L. ReV. 191 (citing Mo ZHANG, Chinese CONTRACt LaW: TheOry AND PRACTICE 15 (Martin Nijhoff Publishers 2006)).

${ }^{157}$ Id. (citing ZHANG, supra note 156, at 31).

${ }^{158}$ Sam Hanson, The Chinese Century: An American Judge's Observations of the Chinese Legal System, 28 WM. MitChell L. Rev. 243, 250 (2001).

${ }^{159}$ Cornish, supra note 37, at 426 (citing Charles Baum, Trade Sanctions and the Rule of Law: Lessons from China, 1 STAN. J. EAST ASIAN AFFAIRS 46, 61 (2001), available at http://www.stanford .edu/group/sjeaa/journal1/china4.pdf).

${ }^{160}$ Safran, supra note 2, at 154 (citing IPR Toolkit: Protecting your Intellectual Property Rights $(I P R)$ in China, EMbassy OF THE UnITED STATES, BeiJing, ChINA, http://beijing.usembassy-china .org.cn/protecting_ipr.html).

${ }^{161} \mathrm{Yu}$, supra note 11, at 214.

${ }^{162}$ Id. (citing Gregory S. Kolton, Comment, Copyright Law and the People's Courts in the People's Republic of China: A Review and Critique of China's Intellectual Property Courts, 17 U. PA. J. INT'L ECON. L. 415, 450 (1996)).

${ }^{163}$ Safran, supra note 2, at 176 (citing Jie Gao, Lecture at the Office of the National Resources Defense Council, Beijing, China: The National Resources Defense Council and the Environment Law Project (June 17, 2010); Interview with Shenjun Chen, Attorney, Shanghai Patent \& Trademark Law Office (June 25, 2010)).

${ }^{164} \mathrm{Id}$.

${ }^{165}$ Id. at 156 (citing Michael Xu, Lecture at the Capital Hotel Beijing in China: Private Equity: Why China Behaves Differently (June 15, 2010)).

\section{A C OS M O P L I T A N C O P R I G H T O M P R I S N}

Volume XV - Fall $2014 \bullet$ ISSN 2164-800X (online) DOI 10.5195/tlp.2014.154 $\bullet$ http://tlp.law.pitt.edu 
copyright cases ${ }^{166}$ are of little value. The negative views of the Chinese judiciary regarding bribery undoubtedly affect the legitimacy of legal decisions. Perhaps the increase in copyright litigation simply means China wants to appear stricter in IPR, while not actually enforcing the law.

In addition to the problems within the judiciary, there are other barriers to litigating copyright cases in China. In the United States, the average total cost of litigating an intellectual property case is between $\$ 1-2$ million. ${ }^{167}$ A similar case brought in China might cost $\$ 100,000$ or less. ${ }^{168}$ Despite the seemingly lower litigation costs, $\$ 100,000$ is worth more in China, based on average salary, than in the United States. In 2011, the average monthly salary in Beijing, which had the highest average salary among Chinese cities, was only $\$ 730$ (or $\$ 8,760$ per year). ${ }^{169}$ Theoretically, it would be near financially impossible for a Chinese copyright holder to go through the Chinese courts, unless that copyright owner committed almost 12 years of savings for litigation. Combined with a shortage of intellectual property lawyers in China, ${ }^{170}$ the cost to litigate and the difficulties in finding legal representation disadvantage Chinese copyright owners. Limited resources, financial burdens, a non-independent judiciary, and lack of enforcement reduce the deterrent value of IPR laws, thus weakening economic incentives that are essential to IP ownership, ${ }^{171}$ both domestically and internationally.

Litigation also remains difficult for foreign companies. Over 60 percent, and in some cities 90 percent, of intellectual property infringement suits brought by multinational companies are successful. ${ }^{172}$ However, China does not implement a discovery process. ${ }^{173}$ "Instead, counsel must rely on its own research, hire private

${ }^{166}$ China Handles More IPR Crimes in 2012, supra note 17.

${ }^{167}$ Safran, supra note 2, at 156 (citing Interview with Donghui Wang, Attorney at Lehman, Lee \& Xu (June 18, 2010)).

${ }^{168} I d$.

169 China's 2011 Average Salaries Revealed, ChINA DAILY (July 6, 2006), available at http://www.chinadaily.com.cn/china/2012-07/06/content_15555503.htm.

${ }^{170} \mathrm{Yu}$, supra note 11, at 214 (citing Jianyang Yu, Protection of Intellectual Property in the P.R.C.: Progress, Problems, and Proposals, 13 UCLA PAC. BASIN L.J. 140, 161 (1994)).

${ }^{171} \mathrm{Yu}$, supra note 36, at 215.

${ }^{172}$ Safran, supra note 2, at 155 (citing Benjamin Bai, China IP Strategies: Don't go to China without Them!, ALLEN \& OVERY (July 20, 2001), http://www.allenovery.com/AOWeb/binaries/ 62394.pdf).

${ }^{173} I d$. at 156 (citing ORDISH \& ADCOCK, supra note 45, at 11).

Journal of Technology Law \& Policy

Volume XV - Fall 2014 • ISSN 2164-800X (online)

DOI 10.5195/tlp.2014.154 $\bullet$ http://tlp.law.pitt.edu 
investigators, or even purchase replicas of the infringing goods at issue." 174 Though a foreign company may pay less in China than it would in the United States, these approximate costs do not include the price of bribing judges. ${ }^{175}$ Therefore, the $\$ 100,000$ litigation cost may be significantly higher when accounting for the need to bribe a judge as well. A more accurate litigation cost comparison would include legal and non-legal costs.

Unfortunately, changing the judiciary's independence, administrative agencies, or procedures is an unrealistic solution because China will likely only desire to act consistently with state policy. The Chinese Constitution states that "the people's courts shall exercise the judicial power independently according to stipulations of laws, free of any interference by administrative agencies, social organizations or individuals." 176 The Chinese Constitution does not contemplate a separation of powers. ${ }^{177}$ Therefore, it is not proper for the United States, or other foreign nations, to simply impose their own values on Chinese sovereignty.

\section{B. Re-Educate the Masses}

Another way to amend the IPR problem in China is to educate Chinese citizens about the benefits of IPR and the damages that artists face when copyright is violated. ${ }^{178}$ However, there is a debate about whether there is something inherent in Chinese culture, specifically "Asian values," that makes embracing a prointellectual property stance difficult. "Asian values" have been defined by some as "authoritarianism, cooperation, harmony, and order."179 Others have looked to "whether any Asian values in intellectual property law and policy actually exist and whether one could identify unified pan-Asian positions in the area." 180 However, the debate is more complicated than simply broadly discussing "Asian values."

${ }^{174}$ Id. (citing Top Ten Trials, Managing Intellectual Property (Dec. 1, 2009), http://www .managingip.com/article/2364977/Top-ten-trials.html).

${ }^{175}$ See Samuel R. Gintel, Fighting Transnational Bribery: China's Gradual Approach, 1 WIS. INT'L L.J. 1 (2013).

${ }^{176}$ ZHANG, supra note 156, at 45 (quoting Ding Bangkai, The Law of Socialist Market Economy 15 (2002)); see XIANFA (Constitution of the People's Republic of China) (1981) (China) (English translation is available at http://www.qis.net/chinalaw/lawtran1.htm).

${ }^{177}$ ZHANG, supra note 156 , at 16.

${ }^{178}$ Yu, supra note 11, at 222 (citing Patrick H. Hu, "Mickey Mouse” in China: Legal and cultural Implications in Protecting U.S. Copyrights, 14 B.U. INT'L L.J. 81, 106 (1996)).

${ }^{179}$ Yu, supra note 97, at 336 (citing see, e.g., Michael C. Davis, Constitutional and Political Culture: The Debate over Human Rights and Asian Values, 11 HARV. Hum. RTS. J. 109, 109 (1998) (noting that Asian values "seems to include authoritarianism, cooperation, harmony, and order as the predominant values of Asian)).

${ }^{180} I d$. at 343.

A COSM OPOLITA N COPYRIGH T COMPARISON

Volume XV - Fall 2014 • ISSN 2164-800X (online)

DOI 10.5195/tlp.2014.154 $\bullet$ http://tlp.law.pitt.edu 
Some scholars argue that cultural differences between China and the United States may impede the "will" of the Chinese to protect IPR, ${ }^{181}$ and that Confucianism, which is merely one type of "Asian value," specifically plays an influential role in how the Chinese view IPR. But simply advocating "[i]ndividualism alone . . does not fully summarize the Western intellectual property position." 182 By educating Chinese citizens, specifically within the context of Confucianism, about the advantages of IPR, and the consequences of inadequate protections, could help alleviate the current problem. ${ }^{183}$

Confucianism, which has influenced Chinese culture for over 2000 years ${ }^{184}$ and continues to influence China today, ${ }^{185}$ has been identified as one of the reasons why China does not seriously protect IPR. ${ }^{186}$ This is true because Confucianism emphasizes understanding of the classics through copying, ${ }^{187}$ and focuses on guidance through moral force and ritual, instead of law. ${ }^{188}$

First, Confucianism emphasizes that writers should replicate rather than compose. ${ }^{189}$ Replicating is not considered "plagiarism," but rather a way to properly preserve the historic record ${ }^{190}$ and respect one's ancestors. ${ }^{191}$ Moreover, replication is viewed as an important means of learning, allowing one to master a subject. The anti-litigation nature of Confucianism demonstrates that it implicitly approves copying works of art, while concurrently discourages people from using a legal system for enforcement. Furthermore, "[s]ocial norms play a large role in

${ }^{181}$ Cornish, supra note 37, at 422 (citing Katherine C. Spelman, Combating Counterfeiting, 417 PLI/Pat 309, 326 (Oct. 1995)).

${ }^{182} \mathrm{Yu}$, supra note 97, at 343.

${ }^{183} \mathrm{Yu}$, supra note 36, at 131, 222 (citing Hu, supra note 178).

${ }^{184}$ Rosen, supra note 156 ("explaining that "Confucius lived from 551-479 BCE and believed in gentlemanly conduct that emphasized good manners, demeanor and gestures, dress and social grace” (citing James M. Zimmerman, China Law Deskbook: A Legal Guide For Foreign-Invested ENTERPRISES 36 (3d ed., vol. 1, 2010))).

185 Junwei Fu, Modern European and ChinESE CONTRACt LAW: A COMPARATIVE STUdy OF PARTY AUTONOMY 9 (2011).

186 See William P. Alford, To Steal a Book is an Elegant OfFense: Intellectual PROPERTY LAW IN CHINESE CiVILIZATION (1995).

${ }^{187}$ Id. at 423 (citing J. DAVID PURPhy, Plunder AND PRESERVATION: CUltural Property LAW AND PRACTICE IN THE PEOPLE's RePUBlic OF China 30 (1995)).

${ }^{188}$ Greenberg, supra note 35, at 173.

${ }^{189}$ Cornish, supra note 37, at 422 (citing John King Fairbank, China: A New History 100001 (1992)).

${ }^{190} I d$.

${ }^{191}$ Id. at 423 (citing PURPHY, supra note 187).

Journal of Technology Law \& Policy

Volume XV - Fall 2014 • ISSN 2164-800X (online) DOI 10.5195/tlp.2014.154 • http://tlp.law.pitt.edu 
securing compliance with the law." 192 In Confucianism, honoring one's parents and elders is much more important than any legal system. ${ }^{193}$

Since Chinese culture emphasizes copying as a means of learning, Chinese citizens may not view copying as a moral wrong, despite infringement being a legal wrong. In other words, if citizens believe something is not morally wrong, they may not care or know that what they are doing is illegal. Importantly, "Confucians believe legal regulations of human conduct could not replace proper moral behavior." 194 Only when moral instruction has failed do punishment and law become necessary. ${ }^{195}$ If this is true, then "litigation [becomes] unnecessary." ${ }^{196} \mathrm{By}$ extension, if copying is viewed as how one acquires mastery of subjects, and law is viewed as only being necessary when morals have failed, then the Western imposition of IPR could result in regulations that are not followed and cases that are infrequently litigated.

Scholars have debated the role of Confucianism in modern day Chinese treatment of IPR. William Alford's book, To Steal a Book is an Elegant Offense, ${ }^{197}$ further explains why the concept of protecting intellectual property is not engrained in Chinese culture. ${ }^{198}$ This book ${ }^{199}$ inspired a generation of intellectual property debate. ${ }^{200}$ Alford reviews how the Qin dynasty (221-206 B.C.) through the Qing dynasty (A.D. 1644-1911) treated intellectual property. ${ }^{201}$ Alford's main thesis is that "imperial China did not develop a sustained indigenous counterpart to intellectual property law, in significant measure because of the character of Chinese political culture." ${ }^{202}$ According to Alford, Western culture's introduction of IPR to

${ }^{192}$ Greenberg, supra note 35, at 183 (citing Mark F. Schultz, Fear and Norms and Rock \& Roll: What Jambands Can Teach Us About Persuading People to Obey Copyright Law, 21 BERKELEY TeCH. L.J. 651, 655 (2006)).

${ }^{193}$ Greenberg, supra note 35, at 174.

${ }^{194}$ Rosen, supra note 156 (citing PATRICIA BlaZey ET AL., The ChinESE COMMERCIAL LegAL SYSTEM 32 (Lara Leeks 2008)).

${ }^{195} \mathrm{Id}$.

${ }^{196}$ Greenberg, supra note 35, at 173 (citing Yu, supra note 126, at 970).

${ }^{197} \mathrm{Yu}$, supra note 97, at 340-41 (citing ALFORD, supra note 186, at 19-29).

${ }^{198}$ Id. (citing ALFORD, supra note 186, at 19-29 (discussing how Confucian culture prevented intellectual property protection from taking root in imperial China)).

\footnotetext{
${ }^{199}$ ALFORD, supra note 186.

${ }^{200} \mathrm{Yu}$, supra note 97, at 341.

${ }^{201}$ Greenberg, supra note 35, at 172.

${ }^{202}$ Id. (quoting ALFORD, supra note 186, at 2).
}

A C OSMOPOLITAN COPYRIGH T COMPARIS ON

Volume XV - Fall $2014 \bullet$ ISSN 2164-800X (online) DOI 10.5195/tlp.2014.154 $\bullet$ http://tlp.law.pitt.edu 
China was unsuccessful because it lacked relevancy in Chinese society. ${ }^{203}$ Still, other authors have challenged Alford's work, ${ }^{204}$ contending that there are no distinct values that establish any pan-Asian positions in the area of intellectual property. ${ }^{205}$

The scholarship that uses Confucianism to explain why intellectual property is not salient in Chinese culture, such as Alford's, does not consider other factors and severely oversimplifies the complexities of Confucianism. For instance, the scholarship fails to account for other influences in China such as Buddhism and Daoism. ${ }^{206}$ Furthermore, given the presence of Confucian influences throughout Asia and East Asia, ${ }^{207}$ one would reasonably believe that other countries would have similar IPR issues. And although copying is a part of Confucianism, "the ability to make transformative use of preexisting works can demonstrate one's comprehension of and devotion to the core of the Chinese culture as well as the ability to distinguish the present from the past through original thoughts." ${ }^{208}$ If China only follows Confucian values, as suggested by Alford, then it actually makes sense that transformative works, which are important in Confucianism, would receive legal protection. Due to this, Alford's emphasis on Confucianism is flawed on its own terms because Confucianism actually supports affording transformative works legal protection.

Despite Confucianism's reverence of transformative works, there is a clear difference between how the United States and China's copyright laws treat them. This is observed in U.S. copyright law, specifically in the Fair Use Doctrine. ${ }^{209}$ In the case of Campbell v. Acuff-Rose Music, Inc., ${ }^{210}$ where a rap group made a

${ }^{203}$ Greenberg, supra note 35, at 173 .

${ }^{204} \mathrm{Yu}$, supra note 97, at 341 (citing Shi Wei, Cultural Perplexity in Intellectual Property: Is Stealing a Book an Elegant Offense?, 32 N.C. J. INT'L L. \& COM. REG. 1, 11 (2006)); see also Ken Shao, The Global Debates on Intellectual Property: What If China Is Not a Born Pirate?, 2010 INTELL. PROP. Q. 341.

$205 \mathrm{Yu}$, supra note 97, at 335.

${ }^{206}$ Id. at 345 (citing Albert H.Y. CHEN, AN INTRODUCTION TO THE LEGAL SySTEM OF THE

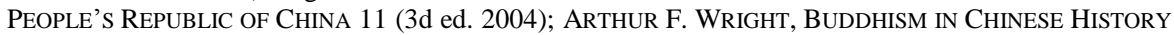
70-85 (1979); Christoph Antons, Legal Culture and History of Law in Asia, in INTELLECTUAL PROPERTY LAW IN ASIA 13, 22-23 (Christopher Heath ed., 2003)).

${ }^{207}$ Yu, supra note 97 , at 345.

${ }^{208}$ Id. at 343.

20917 U.S.C. $\$ 107$ (2012) (explaining that certain fair uses do not infringe a copyright owner's exclusive rights under $\S 106)$.

${ }^{210}$ Campbell v. Acuff-Rose Music, Inc., 510 U.S. 569 (1994).

Journal of Technology Law \& Policy

Volume XV - Fall 2014 • ISSN 2164-800X (online)

DOI 10.5195/tlp.2014.154 $\bullet$ http://tlp.law.pitt.edu 
parody of the Roy Orbison song, "Oh, Pretty Woman," 211 the U.S. Supreme Court recognized the transformative value of the parody in allowing for the possibility of fair use. ${ }^{212}$ While Chinese laws protect transformative works, there are problems with enforcement and the transformers' ability to protect themselves against copyright infringement.

Chinese copyright law has not developed to meaningfully protect transformative works such as parodies. ${ }^{213}$ For example, in a work titled The Bloody Case That Started From a Steamed Bun, ${ }^{214}$ a video blogger named $\mathrm{Hu} \mathrm{Ge}$ attempted to parody the movie The Promise. ${ }^{215}$ The director of The Promise, Chen Kaige, sued $\mathrm{Hu}$ Ge for defamation and other copyright violations. ${ }^{216}$ Although the plain text of Chinese law technically protects transformative works, and despite the fact that the "Steamed Bun" case never went to court, the argument remains that the parody appeared to violate Chinese copyright law. ${ }^{217}$ If this is the case, then the Confucian ideal supporting transformative works is not protected under Chinese law. Thus, relying on Confucianism to explain a weak IPR regime is faulty reasoning; if Confucianism was a dominant factor, then elements that are important in Confucianism, like transformative works, would logically possess stronger protection in China.

Furthermore, simply using Confucianism to explain why intellectual property is not engrained within Chinese culture implicitly suggests that Western values are "better" than Eastern values. Teemu Ruskola ${ }^{218}$ uses the idea of legal orientalism to demonstrate how judgments of other cultures reflect one's own set of values. ${ }^{219}$ Ruskola explains that legal orientalism uses the term "rhetoric of law" to describe the independent way of calling attention to scholars' personal prejudices. ${ }^{220} \mathrm{He}$

${ }^{211} I d$. at 572 .

${ }^{212} I d$. at 594.

${ }^{213}$ See generally Rogoyski \& Basin, supra note 52, at 263 (arguing that Chinese copyright law does not properly protect transformative uses or parodies of copyrighted materials and that China should modify its copyright laws to better protect transformative/parody works).

${ }^{214} I d$. at 240 (citing Dexter Roberts, A Chinese Blogger's Tale, Bus. WK., Mar. 2, 2006, available at http://www.businessweek.com/globalbiz/content/mar2006/gb20060302_026709.htm).

${ }^{215} I d$. at 239.

${ }^{216} I d$. at 240.

${ }^{217} I d$. at 243 .

${ }^{218}$ Professor of Law at Emory University School of Law and expert in Chinese law, comparative law, and international legal history and theory.

${ }^{219}$ Teemu Ruskola, Legal Orientalism, 101 Mich. L. REV. 179, 184-85 (2002).

${ }^{220} \mathrm{Id}$. at 193 . 
criticizes how scholars believe that the Chinese "conflate law and morality, or law and custom" because this allows Westerners to patronize Chinese law while resupporting their Western-based belief systems. ${ }^{221}$ But by acknowledging that "the description of foreign law ... is always an instance of comparative law," scholars can be cognizant of their own belief structures as a reflection of the normative judgments they make about other countries and their legal systems. ${ }^{222}$ Equating the value given to IPR with Asian values "underestimates both the historical ruptures of colonization and the present forces of global interaction." 223 "[I]t is simply just misleading and overly simplistic to describe piracy and counterfeiting as a cultural problem." 224

Based on the foregoing analysis, while scholars' emphasis on Confucian values is perhaps given too much weight, Confucianism is still relevant to the concept of IPR protection in China, and its emphasis on education may in fact be helpful in convincing China to better protect IPR. Confucianism emphasizes education, rather than law, as the best means for guiding people. ${ }^{225}$ However, several practical problems arise with this solution.

The first problem with re-education is that prior attempts have been unsuccessful. In 1995, there was an Action Plan, which called for education, ${ }^{226}$ followed by the signing of a seven-year agreement between the Shanghai Municipal People's Government, Shanghai Intellectual Property Administration, and the American International Education Foundation in an effort to strengthen IPR. ${ }^{227}$ However, nothing in the press indicates the success or failure of these programs, so perhaps the finger-pointing to cultural reasons is problematic. If using re-education programs has failed in the past, then "re-education" may not be a realistic solution to actually improving copyright protection.

The second problem with re-education is that, regardless of whether Confucianism is a cause of IPR violations in China, change would be difficult to

\footnotetext{
${ }^{221}$ Id. at 187.

${ }^{222} I d$. at 192

${ }^{223}$ Yu, supra note 97, at 348 (citing Simon S.C. Tay, Human Rights Culture, and the Singapore Example, 41 MCGILL L.J. 743, 747 (1996)).

${ }^{224}$ Id. at 350 (citing Peter K. Yu, Four Common Misconceptions About Copyright Piracy, 26 LOY. L.A. INT'L \& COMP. L. REV. 127, 131-34 (2003)).

${ }^{225}$ Kalscheur, supra note 75, at 515.

${ }^{226} \mathrm{Yu}$, supra note 36, at 148.

${ }^{227}$ Id. (citing Elevating Intellectual Property Rights (IPR) in China's Largest City and Leading Industrial Center, American InTERnATIONAL EduCATION Foundation (Oct. 28, 2004), http://www .aief-usa.org/ipr/workshop/shanghai_2004.htm.

Journal of Technology Law \& Policy

Volume XV - Fall $2014 \bullet$ ISSN 2164-800X (online) DOI 10.5195/tlp.2014.154 $\bullet$ http://tlp.law.pitt.edu
} 
administer. "[C]hanging social norms is, in reality, a very complex challenge."228 People generally comply with laws when the majority feels that the rest of society is also cooperating and that "the results of their cooperation are equitable." 229 Furthermore, similar to forcing China to have an independent judiciary, ${ }^{230}$ it is rather bourgeois for Western scholars to propose that Chinese citizens need to be re-educated. Such a forced solution implies Western superiority and continues to impose Western values on another sovereign nation.

Perhaps it is Western scholars that should be re-educated so that they can better understand Chinese values and how they relate to China's legal system, although this could be problematic on its own. Instead, American citizens could be educated so they can better understand Chinese culture. If both parties understood each other to a greater degree, a more constructive strategic partnership between the U.S. and China could be formed. ${ }^{231}$ If U.S. investors educate themselves about Chinese culture, through such programs as exchanges with professionals, academics, and government officials, ${ }^{232}$ then it would help facilitate successful business transactions. ${ }^{233}$ American education is especially important given the United States and the media's limited understanding of China. ${ }^{234}$

Overall, despite the debate among scholars concerning the cultural reasons as to why China does not protect IPR, re-educating the Chinese public is not the best solution. It implies Western dominance and blames Confucianism for a weak IPR regime, which not only oversimplifies Confucianism but also continues to impose the United States' will on Chinese sovereignty.

\section{Show China the Money}

Chinese copyright law has primarily been influenced by an American-led, top-down system of pressure that supports American trade and economic interests. ${ }^{235}$ If the hope is to bring China into the fold of the global economy, then

\footnotetext{
${ }^{228}$ Greenberg, supra note 35, at 173 (citing Shultz, supra note 192, at 651, 667-68).

${ }^{229}$ Id. at 186.

${ }^{230}$ See Part III-A supra discussing the independent judiciary solution.

${ }^{231}$ Yu, supra note 36, at 183 (citing Xiaohao Ding, Basis for a Constructive Strategic Partnership Between China and the United States, in OuTLOOK FOR U.S.-ChINA RELATIONS 161, 167 (Peter Koehn \& Joseph Y.S. Cheng eds., 1999)).

${ }^{232} I d$.

${ }^{233}$ See Mark A. Scott, China's Influence on the American Legal System Resulting from China's Rise to Power, 32 Suffolk Transnat'L L. Rev. 51, 72 (2008).

${ }^{234} I d$. at 185.

${ }^{235}$ Rogoyski \& Basin, supra note 65 , at 249.

A COSMOPOLITAN COPYRIGH T COMPARISON

Volume XV - Fall 2014 • ISSN 2164-800X (online) DOI 10.5195/tlp.2014.154 $\bullet$ http://tlp.law.pitt.edu
} 
"the United States needs to convince Chinese leaders why economic integration will benefit China and improve its standing in the international community." ${ }^{236}$ Doing so could help China increase international business transactions and also become more legitimate as a world player. ${ }^{237}$ Yet China is hesitant to have a strict IPR regime because it would mainly benefit foreigners, not Chinese citizens. ${ }^{238}$ This position would change if copyright became a way for Chinese creators and businesses to profit. If protecting IPR would allow Chinese citizens and the PRC to make money, then IPR might be better enforced. One way that intellectual property and copyright can become more profitable in China is if China follows the example of Japan.

Japan's history with intellectual property rights illustrates how a country can profit from increased IPR enforcement. "Japan has improved [intellectual property protection] considerably in the last two decades," a far cry from its widely criticized IPR regime of the early 1980s. ${ }^{239}$ Originally, the Copyright Act in Japan did not protect programming language, rules, or algorithms for computer and software programs. ${ }^{240}$ In the 1970s and 1980s, Japan became a major player in the consumer electronics and computer industries. ${ }^{241}$ Because of this, Japan's Copyright Act was amended in 1986 to include protection for circuit layouts of

\footnotetext{
${ }^{236} \mathrm{Yu}$, supra note 36, at 196.

${ }^{237}$ Id. at 197 (citing Peter K. Yu, Succession by Estoppel: Hong Kong's Succession to the ICCPR, 27 Pepp. L. ReV. 53, 100-02 (2000)).

${ }^{238} \mathrm{Yu}$, supra note 36, at 207.

${ }^{239}$ Yu, supra note 97, at 354 (citing Michael P. RYAN, Playing BY THE RUlEs: AMERICAN TRAde Power AND DiPLOMACY IN THE PACIFIC 16-17 (1995)).

${ }^{240}$ H. Stephen Harris, Jr., Competition Law and Patent Protection in Japan: A Half-Century of Progress, a New Millennium of Challenges, 16 COLUM. J. ASIAN. L. 71, 85 (citing MitsuO MATSushita \& Thomas J. Schoenbaum, JAPANESE INTERNATIONAL TRADE AND INVESTMENT LAW $221(1989))$.

${ }^{241}$ JAPAN, Revolutionary Change: County Data, COUNTRY-DATA.COM (Jan. 1994), available at http://www.country-data.com/cgi-bin/query/r-7176.html (stating that "Although the investment costs were high, many energy-intensive industries successfully reduced their dependence on oil during the late 1970s and 1980s and enhanced their productivity. Advances in microcircuitry and semiconductors in the late 1970s and 1980s also led to new growth industries in consumer electronics and computers and to higher productivity in already established industries. The net result of these adjustments was to increase the energy efficiency of manufacturing and to expand so-called knowledge-intensive industry. The service industries expanded in an increasingly postindustrial economy. Structural economic changes, however, were unable to check the slowing of economic growth as the economy matured in the late 1970s and 1980s, attaining annual growth rates no better than 4 to 6 percent. But these rates were remarkable in a world of expensive petroleum and in a nation of few domestic resources. Japan's average growth rate of 5 percent in the late 1980s, for example, was far higher than the 3.8 percent growth rate of the United States.").
}

\begin{tabular}{l} 
Journal of Technology Law \& Policy \\
\hline
\end{tabular}

Volume XV - Fall 2014 • ISSN 2164-800X (online)

DOI 10.5195/tlp.2014.154 • http://tlp.law.pitt.edu 
semiconductor integrated circuits. ${ }^{242}$ Such protections allowed Japan to focus on the success of these growing industries, which led to increases in foreign investment, and an average of four percent real economic growth in the 1980s. ${ }^{243}$

There are important parallels between Japan and China. "In 1994 alone, the United States suffered losses of over $\$ 1.265$ billion due to intellectual property piracy in Japan." 244 In addition, Japan was itself subject to piracy of its own copyrights and patents. As such, people in the country realized they needed to begin protecting intellectual property in order to serve the country's best interest. ${ }^{245}$ Additionally:

The Japanese went through a similar stage [to the Chinese] in their development-copying many American and European products. Japanese companies and the government cracked down on the practice when Japanese companies needed laws to protect their intellectual property rights. It is assumed that the same will happen in China as the country becomes more developed and its companies and business practices more mature. ${ }^{246}$

Moreover, current anti-Chinese rhetoric reflects the anti-Japanese rhetoric from the 1980s. ${ }^{247}$ One scholar has posited that:

${ }^{242}$ Harris, supra note 240, at 85 (citing the Copyright Act, as amended by Law 64, 1986).

${ }^{243}$ JAPAN, supra note 241.

${ }^{244}$ John D. DeFrance, Comment, Sound Recordings: Copyright and Contractual Differences Between the United States and Japan, 21 Loy. L.A. INT'L \& COMP. L. ReV. 331, 336 (1999) (citing Eric H. Smith, Worldwide Copyright Protection Under the TRIPs Agreement, 29 VAND. J. TRANSNAT'L L. $559,562(1996))$.

${ }^{245} I d$.

${ }^{246}$ Jeffrey Hayes, Pirating and Counterfeiting in China, available at http://factsanddetails.com/ china.php?itemid $=356$.

${ }^{247}$ Scott, supra note 233, at 54 (citing Keith Bradsher, Like Japan in the 1980s, China Poses Big Economic Challenge, N.Y. TiMEs, Mar. 2, 2004, at A1 (discussing China's economic potential ... [and that] China's cheap work force, huge markets, and vast population make China "an even greater longterm economic challenge to the United States than Japan seemed to be in the 1980's"); see also Amelia Newcomb, Is China Japan All Over Again?, ChristiAn SCI. Monitor (Aug. 19, 2005), available at http://www.csmonitor.com/2005/0819/p01s04-woap.html (comparing modern sentiment toward China's economic growth to similar view of Japan's rapid growth during 1980s)).

\section{A C OS M O P L I T A N C P Y R I G H T O M P R I S N}

Volume XV - Fall $2014 \bullet$ ISSN 2164-800X (online) DOI 10.5195/tlp.2014.154 $\bullet$ http://tlp.law.pitt.edu 
[I]f China follows the precedents set by the United States and Japan, its economic and technological conditions will eventually reach a crossover point where the country considers it to be in its self interests to provide stronger protection and enforcement of intellectual property rights. Once China has reached that point, it will not only offer stronger protection and enforcement within the country but will also demand other countries to do the same-similar to the European Union, the United States, and Japan. ${ }^{248}$

If China does not want to emulate Japan due to tensions from World War II, China can realistically follow other countries' footsteps in developing products that would encourage better intellectual property protections. There are other economies in regions such as Hong Kong, Singapore, South Korea, and Taiwan that show how other Asian countries have benefited and profited from having greater IPR protections. ${ }^{249}$ If the Chinese government could find a profitable niche industry that necessitates the development of intellectual property, then China would have more incentive to protect IPR. For example, one study from 2006 by the Business Software Alliance suggests that "China could create 2.6 million new jobs in information technology if piracy was sharply reduced." ${ }^{250}$ Developments such as these would likely influence the country to move forward in providing better protections for copyright and other forms of intellectual property.

From a micro-monetary standpoint, China could emphasize that internal piracy can also destroy the livelihoods of Chinese innovators. ${ }^{251}$ "Despite its huge size, the Chinese economy is still working to adapt to the Western [economic] model." ${ }^{252}$ Chinese authors have to battle both piracy within China and the competition between their products and pirated works from abroad. ${ }^{253}$ As China's free market continues to grow, piracy hurts the entire Chinese population, and not

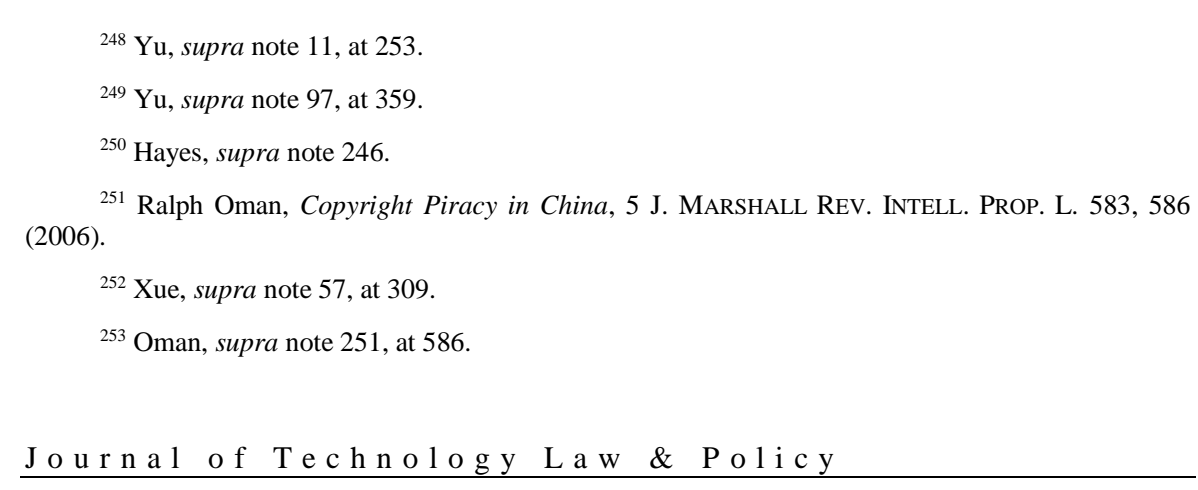

Volume XV - Fall $2014 \bullet$ ISSN 2164-800X (online) DOI 10.5195/tlp.2014.154 • http://tlp.law.pitt.edu 
just wealthy Chinese businessmen or foreigners. ${ }^{254}$ Counterfeiting goods results in billions of dollars' worth of losses, as foreign investors are deterred from entering the Chinese market. 255 "By communicating to the Chinese that piracy is not just a question of robbing a distant foreign company, but a pervasive problem with real consequences at home, the incentive to combat piracy will increase dramatically. ${ }^{256}$

Overall, China can follow in the footsteps of Japan, Hong Kong, Taiwan, Singapore, and South Korea by incentivizing creations from local businesses and Chinese citizens. Doing so would encourage Chinese creativity, while increasing its gross domestic product. If China can profit from its domestic intellectual property creations, then it will likely take IPR enforcement more seriously in order to protect its own products and works. This third solution is superior to the first and second, which instead attempt to use external influences to force China to change. ${ }^{257}$ The third solution reframes intellectual property rights and copyright as a means by which China can succeed in the international arena, without submitting to Western pressures. Thus, framing intellectual property as a profitable resource is the most realistic and just solution given that it embraces China's transition to a market economy and does not impose Western values and laws on its government and legal traditions.

\section{CONCLUSION}

Enforcing IPR will remain an important issue in Asia for at least the next decade. ${ }^{258}$ Within China, piracy continues "despite the fact that [it] is now an important creator of books, motion pictures, music and software." ${ }^{259}$ Piracy harms Chinese authors, and if the government wants to encourage creativity, strong copyright protection should be given to both foreign and domestic authors. ${ }^{260}$ As one scholar notes:

\footnotetext{
${ }^{254}$ Cornish, supra note 37, 435-36 (stating that "As China's free market evolves, the effects of piracy are no longer merely hurting foreigners or a select group of wealthy Chinese businessmen, but the population at large").

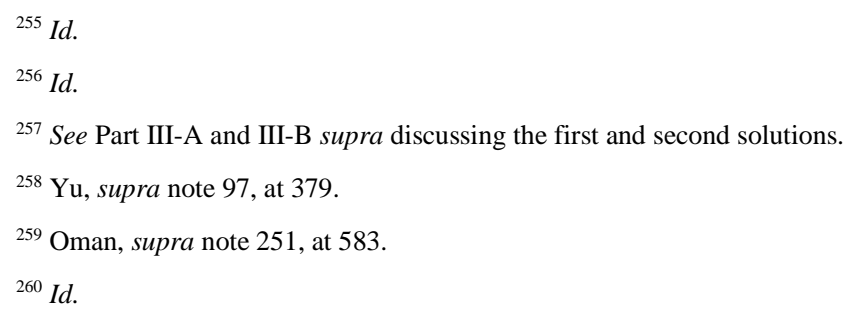


Copyright is a very modern, humane doctrine. At its core are ideals about the worth of authorship, the dignity of human labor, and about how property is created and protected. Copyright is also about respect for both men and women everywhere. Creators are working people who need copyright protection to earn a living, whether they are Chinese or American. ${ }^{261}$

Unfortunately, it is neither easy nor practical for the United States to simply exert pressure on China to enforce change. Intellectual property intertwines with democracy and the promotion of free speech, ${ }^{262}$ suggesting that copyright law can be used to induce democracy in authoritarian regimes. ${ }^{263}$ In fact, "[b]eing the 'engine of free expression,' copyright 'provides an incentive for creative expression on a wide array of political, social, and aesthetic issues, thus bolstering the discursive foundations for democratic culture and civic association." "264 The solutions to change the judiciary or re-educate China are problematic because they essentially force China to embrace Western values. Attempts to change the judiciary in China or re-educate the Chinese population could make the government weary, especially given the skepticism surrounding democratic influences that are contrary to maintaining order in a socialist country or supporting state socialist policies. More realistically, the third solution, which frames copyright as a way for China to make money from Chinese innovators, especially in light of the shift from a planned economy to a market economy, would encourage China to more seriously protect IPR and copyright while maintaining a comfortable distance from the democratic and human rights agenda that other scholars may be trying to promote. Thus, framing copyright protection as a profitable endeavor is the most realistic of the three solutions. It will not only strengthen copyrights in China, encouraging the country's citizens to create works of art, but will also implement such changes in a way that respects China's sovereignty and its shift to a market economy instead of forcing China to blindly follow Western values.

${ }^{261} I d$.

${ }^{262}$ Rogoyski \& Basin, supra note 65, at 237.

${ }^{263}$ Id. at 257 (citing Neil Netanel, Asserting Copyright's Democratic Principles in the Global Arena, 51 VAND. L. REV. 217 (1998)).

${ }^{264} \mathrm{Yu}$, supra note 11, at 212; Neil Weinstock Netanel, Copyright in a Democratic Society, 106 YAle L.J. 283, 289 (1996) (citing Harper \& Row, Publishers, Inc. v. Nation Enters., 471 U.S. 539, 558 (1985) (stating that the Framers of the Constitution intended copyright to be the "engine of free expression")).

Journal of Technology Law \& Policy

Volume XV - Fall $2014 \bullet$ ISSN 2164-800X (online)

DOI 10.5195/tlp.2014.154 $\bullet$ http://tlp.law.pitt.edu 